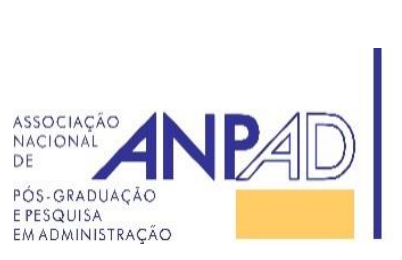

Available online at http://www.anpad.org.br/bar

BAR, Rio de Janeiro, v. 15, n. 1, art. 5, e170112, 2018

\title{
Responsible Leadership Research: A Bibliometric Review
}

\author{
Tânia Marques ${ }^{1}$ \\ Nuno Reis ${ }^{1}$ \\ Jorge F. S. Gomes ${ }^{2}$
}

Instituto Politécnico de Leiria, Escola Superior de Tecnologia e Gestão, Portugal ${ }^{1}$ Universidade de Lisboa, Instituto Superior de Economia e Gestão, Portugal ${ }^{2}$

Received 26 September 2017; received in revised form 23 January 2018; accepted 23 February 2018; first published online 26 March 2018.

Editor's note. Maria Luisa Mendes Teixeira served as Action Editor for this article. 


\begin{abstract}
Political, religious, sports and business leaders across the world have been under scrutiny regarding allegedly unethical behaviors. The current study analyzes the use of responsible leadership in management research. Using a sample of 64 articles published in SSCI-indexed journals over 10 years (2006-2016), we carried out a bibliometric analysis to understand the intellectual structure of the responsible leadership literature. The results of authorship, citation and co-citation, and factor analyses reveal the most prolific authors and the most notable journals writing and publishing on responsible leadership. The most cited works are theoretical, using Western frameworks and cultures, and focus on the concept of responsible leadership; only a few empirical/case study articles appear. Also, the most prevalent links are between theoretical works and highlight the conceptualization, understanding, and roles and parameters of responsible leaders. Six distinct factors emerge, denoting the groups of studies devoted to the evolution of leadership, transformational leadership, stakeholder theory and leadership, conceptualization and understanding of the topic, and roles of responsible leaders. These various research topics show the central tenets of responsible leadership, as well as the existing gaps in the existent literature.
\end{abstract}

Key words: responsible leadership; bibliometrics; bibliometric review; citation and co-citation analysis; factor analysis. 


\section{Introduction}

Responsible leadership is fast becoming a hot topic both in academia and in the business world. Two reasons seem to compete to boost this interest. Firstly, the growing complexity and connectedness in society, in which organizations, workers, clients, suppliers, public entities, environmental institutions, and citizens in general are becoming interdependent pieces of a gigantic and dynamic social puzzle. Secondly, the increasing awareness, public interest and intervention in financial crises, unemployment, massive layoffs, downsizings, environmental problems, corporate scandals and unethical misconduct in business. Managers and leaders' responsibilities and ethical behavior have been receiving higher levels of attention (Shi \& Ye, 2016); hence corporate and managerial responsiveness has been under public scrutiny more than ever (Pfeffer, 2015). In his seminal paper, Stodgill (1950) highlighted leadership as one of the world's oldest concerns, as exemplified by Homer's book the Iliad and the Greek heroes. According to Stogdill (1950, p. 3), leadership can be considered as "the process (act) of influencing the activities of an organized group in its efforts toward goal setting and goal achievement". The word influence has in fact become part of many definitions of leadership, thus showing that leadership is a relational process in which one part exerts some kind of inducement over another part. A very popular definition is Yukl's (2006), who sees leadership as a process in which certain individuals understand and influence what needs to be done and how to do it, as well as facilitate individual and collective efforts to accomplish shared objectives.

Responsible leadership advances the existing definitions of leadership and takes into account the way leaders use their power. Responsible leadership points out that the influencing power of leaders should be used to improve everybody's lives, rather than contributing to the destruction of value of individual careers, organizations, economies, and societies. In that sense, responsible leaders influence all stakeholders (internal and external), not just employees. Responsible leadership is therefore distinct from other perspectives of leadership (e.g. transactional/transformational or ethical) as it is anchored in the assumption that leaders must balance different (and potentially conflicting) sets of interests. Responsible leadership, thus, becomes a key theme to understand, and one which organizations and decision-makers alike should stimulate and educate people about.

Although a recent concept, responsible leadership has attracted much research attention (Shi \& Ye, 2016), but literature has failed to offer a systematic description of the key ideas, concepts and theoretical approaches underlying the research. Thus, no organized and systematic review has been offered, leaving the knowledge on the field scattered through numerous publications. Reviewing the extant knowledge in a field allows understanding of the main theoretical approaches and themes, as well as identification of the gaps and key opportunities for further advancement of the field. Our bibliometric review contributes to fill this research gap by offering an objective analysis of the responsible leadership field.

The study uses bibliometric techniques to map the knowledge structure of responsible leadership research for the last decade (2006-2016). Bibliometric studies focus on published books, documents and journals aiming at the measurement of knowledge or the understanding of publications (Teixeira, Iwamoto, \& Medeiros, 2013). Bibliometric studies allow for a more systematic analysis of the literature and are less prone to researcher biases given the use of a quantitative approach. Using bibliometric techniques allows characterizing the existing knowledge and the underlying intellectual structure of responsible leadership literature. Hence the current work analyzes responsible leadership articles in journals indexed in the Thomson Reuter's ISI Social Science Citation Index (SSCI). The time-range for the articles retrieved was 2006-2016 (October). Four analyses are performed: authorship, citation, cocitation and factor analysis of the existing research on responsible leadership.

The paper is structured as follows. Firstly, a brief theoretical background is given with regards to responsible leadership. Secondly, the methodology is explained, including design, sample, procedures and analyses. Thirdly, the results are put forward. Finally, the paper ends with a discussion and concluding remarks, including contributions, limitations and future research avenues. 


\section{Theoretical Background}

Leadership has been one of the most researched topics in organizational studies, management, and many other related areas. Leadership is said to be paramount for key organizational issues such as performance (e.g. Howell \& Avolio, 1993), but also for many other individual, group, and organizational indicators (e.g. G. Wang, Oh, Courtright, \& Colbert, 2011). In recent years, research has focused on the goodness of leadership, i.e., the characteristics and behaviors that, in the process of leadership help to develop individuals, encourage positive relationships, support ethical and moral standards, and stimulate efficient social dynamics in organizations. Such has been the center tenet of transformational leadership, which sees leaders and workers engaging in interactional-based relationships, exchanging values and other personal and professional-type of stimulus (Tal \& Gordon, 2016). Transformational leadership assumes that workers evolve as professionals and persons, via the influencing capacity of leaders in shaping vision, moral values, coherence, inspiration, and ethics (Burns, 1978).

Even though the advancements in theory propose a generic positive feeling about the goodness of leadership, practice is plagued with evil leadership in all sectors and organizations (Pfeffer, 2015). In fact, in recent years the world has witnessed various social protests and movements based on individuals and workers' disillusionment with an economic model grounded on efficiency and profits, which are the basic premises of capitalism. The expression "Capitalism is under attack" (Beinhocker \& Hanauer, 2014, p. 160) characterizes such general feelings, and although governments' responsibility appears to be difficult to substantiate in the immense political web of issues and lack of trust, business leaders may start operating changes to use their influence and trust for the better (Maak \& Pless, 2006a). Thus, a paradigm shift is needed for leaders in a business setting.

The paradigm shift for business leaders has been increasingly populated with new notions, concepts, and theories of leadership, and as something that needs to bring a more positive impact into human lives. Recent terms include servant, ethical, authentic, spiritual and humble leadership. In a similar vein, the notion of responsible leadership has caught considerable attention, which was initially understood by Maak and Pless (2006b, p. 99) as "a social-relational and ethical phenomenon, which occurs in social processes of interaction". The authors see responsible leadership within a broad framework, as all stakeholders that interact with the leader are considered followers, whether they are from inside or outside the organization. Hence, leaders need to constantly adapt their styles and behaviors to these various internal and external stakeholders from inside or outside the organization. In the literature, this has been paralleled by an increasing exploration of more complex, shared and collective leadership types (Tal \& Gordon, 2016), in which the role of the leader is essentially relational, as well as one of coordinating and cultivating relationships between all stakeholder groups.

In this sense, responsible leadership is distinct from other leadership theories, such as transactional/transformational leadership, or ethical leadership, because its ethos is rooted in the need to maintain a complex and dynamic balance between various - and often conflicting - sets of interests. For accomplishing such challenging goals, Voegtlin, Patzer and Scherer (2012) assert that responsible leadership ought to maintain an ethical perspective, while assuring the requisites for efficiency and efficacy. Thus responsible leadership is also likely to have a wider and deeper impact on multiple outcomes. Wider, because more stakeholders now need to be included inside the overall leadership sphere; and deeper, because the effects of leadership at individual levels interact to cause further effects. Although much is still to be explored regarding responsible leadership, it is likely that the concept represents a radical new view of leadership.

Tal and Gordon (2016) have recently published a bibliometric review of the current approaches to leadership, dividing them into two main categories: those that have appeared since the mid-20 century, and which treat leadership as a hierarchical system on a stable framework; and those more recent approaches that focus on a more complex, flexible and changing framework. Responsible leadership, probably due to its newness and more relational global approach, is truly a very recent arrival in the literature, with the first works making their debut in the beginning of the $21^{\text {st }}$ century. Despite 
being recent, approximately within the last decade, the topic has gained a high level of attention in management research (Shi \& Ye, 2016), which nevertheless has not been accompanied by a systematization of the ideas, concepts, and key theories already being used by active researchers. Such is the purpose of the current research, which intends to organize and give structure to the existing literature on responsible leadership.

\section{Methodology}

\section{Design}

Bibliometric studies have gained popularity in the Management area in recent years (Teixeira et al., 2013), and are used as an alternative to traditional literature reviews (Ferreira, Li, Reis, \& Serra, 2014). Bibliometrics consists of the "quantitative study of physical published units, or of bibliographic units, or of the surrogates of either" (Broadus, 1987, p. 376). Some recent bibliometric studies include: Teixeira, Iwamoto and Medeiros (2013), in the case of bibliometric studies in administration published in top Brazilian journals; Pinto, Serra and Ferreira (2014), on research into culture in international business; Sriwannawit and Sandström (2015), on diffusion research; Cullen (2015), on sustainability and business and management education; Oorschot, Hofman and Halman (2015), on innovation adoption; Lindahl, Stenling, Lindwall and Colliander (2015), on sports and exercise; and William, Tripp-Reimer, Daack-Hirsch and DeBerg (2016), on genomic nursing. A number of recent bibliometric studies have also been published in the leadership literature, such as Batistič, Černe and Vogel (2017) and Tal and Gordon (2016). Despite the abundant bibliometric studies, none has, to the best of our knowledge, addressed responsible leadership.

\section{Sample}

The empirical data was retrieved from Thomson Reuters' ISI Web of Knowledge (www.isiknowledge.com, principal collection of Web of Science), through SSCI (Social Sciences Citation Index), covering all available years up to and including 2016 (October). We selected the Web of Science as the sample source due to its reputation and its data availability; we followed the procedures of other bibliometric studies in Management. The main reason for using SSCI is that this is a worldwide recognized database. Furthermore, it has also been used in other recent studies (e.g. Ferreira et al., 2014; Pinto, Serra, \& Ferreira, 2014; Vogel \& Masal, 2015). The ISI-indexed journals are highly-ranked in social sciences (G. G. Wang, Gilley, \& Sun, 2012) and scholars arguably seek to publish research that drives a field in highly-ranked outlets, namely in influential high impact-factor journals (Furrer, Thomas, \& Goussevskaia, 2008). Thus, highly-ranked journals are more likely to make a more accurate representation of the research in a field than lower ranked journals (Ferreira et al., 2014). Moreover, "this [ISI Web of Knowledge Core collection] database has previously been used across a wide range of scientometrics studies, and it provides broad coverage in the social sciences and in the arts and humanities" (Gurzki \& Woisetschläger, 2017, p. 148). In conclusion, the Web of Science offers the most adequate and robust data source for this bibliometric review.

Upon reviewing the existing literature, we used the key words responsible leader* in the Topic field in SSCI; this allowed a wider coverage, as it searches the title, the key words and the abstract to ensure a wider coverage (Ferreira et al., 2014). The * wildcard character was used to ensure the maximum variation as the search could include leader, leadership, etc. To guarantee that the sample was accurate and complete, we screened the articles by reading both title and abstract of all published articles and reviews (Ferreira et al., 2014).

After extracting the data from the database, the bibliographic data were thoroughly cleaned in order to adjust to different spellings and mistakes, and also in order to eliminate some eventual typing 
errors. This data collection procedure returned a total of 64 works, which were published between 2006 and October of 2016.

\section{Procedures and analyses}

The term bibliometrics is frequently credited to Pritchard (1969), and is defined as "the application of mathematics and statistical methods to books and other media of communication" ( $p$. 348). Bibliometric methods have been applied in various forms for about a century (Hood \& Wilson, 2001), and they are suitable for general overviews of a research field and the analysis of leading researchers (Bjork, Offer, \& Soderberg, 2014). To describe the content and evolution of research in responsible leadership research, authorship, citation, co-citation and factor analyses were conducted in this study. For the bibliometric analyses, Bibexcel software (Persson, Danell, \& Wiborg, 2009) was used. For the co-citation analysis the Ucinet 6 software was selected to plot the illustrations of the relations in the co-citation matrix, identifying the strongest links in responsible leadership research. To increase the reliability of eventually miscoded authorship of the data, a manual normalization was done, correcting any differences, typos and other inconsistencies.

We performed an authorship analysis to identify the most productive authors and their impact in the academic community. Authorship analysis identifies authors with a high number of papers in a given field of research or, in other words, shows prolific scholars with a high quality track record which have gained the approval of the peers (Ramos-Rodríguez \& Ruíz-Navarro, 2004).

Citation analysis is one of the most used bibliometric techniques (Teixeira et al., 2013) and one of the earliest methods (Ma, 2009). Its importance lies in the fact that the most cited works are recognized as having the greatest impact on the field of study (Ferreira, 2011; López-Duarte, VidalSuárez, González-Díaz, \& Reis, 2016). Citation analysis assumes that authors tend to cite articles that they consider essential to support their argumentation lines (White \& McCain, 1998). Performing a citation analysis requires analyzing the reference list of the works in the sample and then computing the frequency of each one. This procedure allows identification of the most influential works which form the knowledge base of research (Ferreira et al., 2014).

To map the intellectual network of a research field we performed a co-citation analysis. This procedure consists of counting pairs of co-cited references from a given field (Ma, 2009; White \& McCain, 1998). As a result, a co-citation matrix emerges, which numerically describes the interconnectedness of the works which form the knowledge base of the field (Ferreira et al., 2014). Therefore, the more often a pair of works is cited in the same article of the sample, the more those two works are connected (Diodato, 1994).

We also performed a factor analysis as a means to understand the field's intellectual structure. Factor analyses allow researchers to identify common elements in a database, which serves as a way to explore higher-order theoretical concepts (Acedo, Barroso, \& Galan, 2006; Charvet, Cooper, \& Gardner, 2008). We relied on the co-citation matrix to conduct factor analysis, after transforming it into a Pearson correlation matrix to determine the similarity between works ( $c f$. Charvet et al., 2008). We performed a factor analysis using a varimax rotation (Charvet et al., 2008) and retained the factors with an eigenvalue greater than 1. Each work was then included in a single factor - the one with the highest loading, as long as the loading was at least 0.4 . We proceeded to interpret the content of each work in each factor to identify the underlying commonalities. The authors discussed the contents of the papers included in each factor, identifying common issues and attributing an umbrella title for each factor. Thus each factor was a proxy for key research themes in the responsible leadership field. 


\section{Results}

We retrieved bibliometric data (author, journal name, article title, authors, key words, year of publication and reference list) for the 64 articles. The first results focus on the time frame of responsible leadership research. Figure 1 shows the frequency distribution of publications on the topic, starting in 2006 and growing from 2009 on.

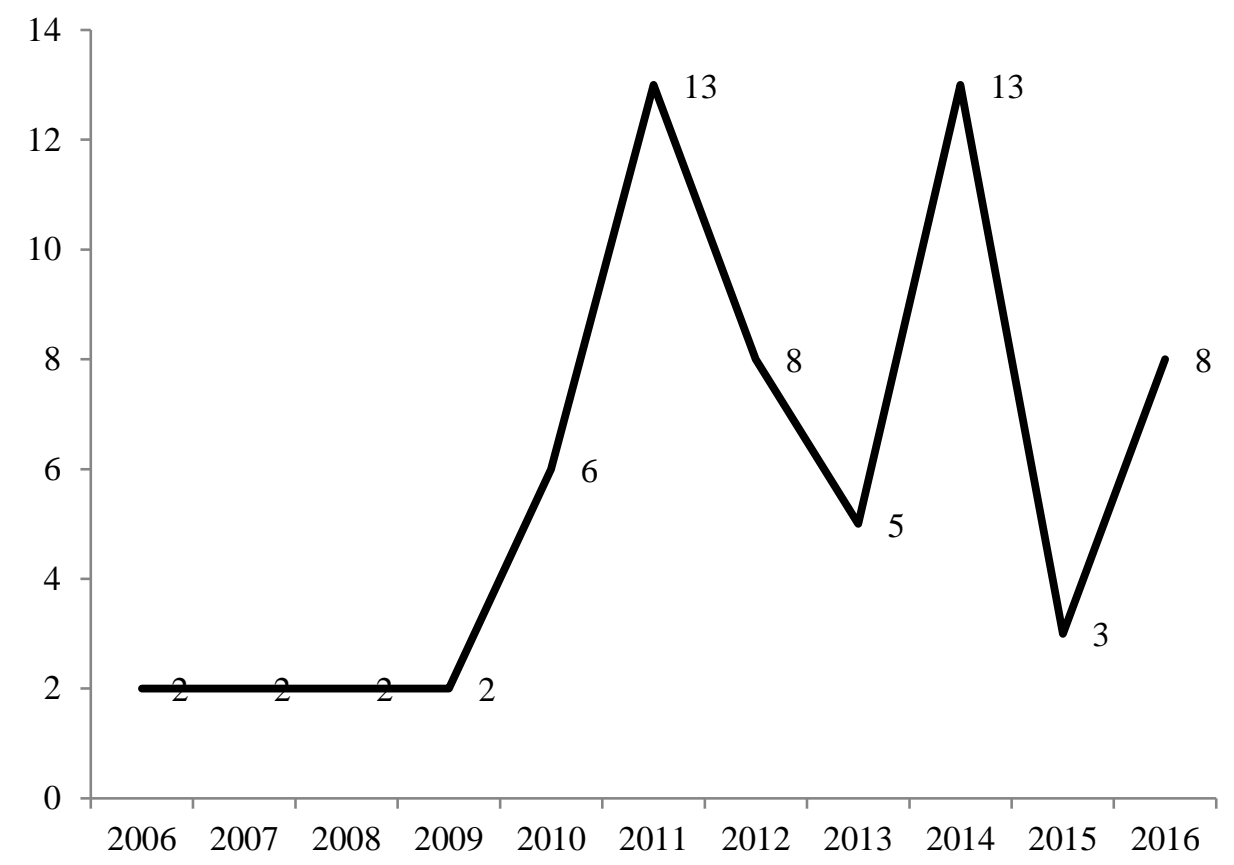

Figure 1. Evolution of Publications: 2006-2016

Source: Data collected from ISI Web of Knowledge. (n.d.). Web of Science. Retrieved from www.isiknowledge.com

Several journals have been publishing on the topic, but Journal of Business Ethics emerges as the one where more publications have appeared: almost half of the existing articles on responsible leadership (a total of 30 articles published out of 64). Table 1 presents the top 10 journals that have published the most articles on responsible leadership in the last decade.

Table 1

Top 10 Journals with the Most Publications on the Topic

\begin{tabular}{clcc}
\hline Rank & Journal Title & $\begin{array}{c}\text { Total } \\
\text { published in } \\
\text { the sample }\end{array}$ & $\begin{array}{c}\% \text { of the } \\
\text { sample } \\
\text { (approx.) }\end{array}$ \\
\hline 1 & Journal of Business Ethics & 30 & $47 \%$ \\
2 & Academy of Management Perspectives & 7 & $11 \%$ \\
3 & Journal of College Student Development & 4 & $6 \%$ \\
4 & Corporate Social Responsibility and Environmental Management & 3 & $5 \%$ \\
5 & Journal of Leadership \& Organizational Studies & 3 & $5 \%$ \\
6 & Leadership \& Organization Development Journal & 2 & $3 \%$ \\
\hline & & & Continues
\end{tabular}


Table 1 (continued)

\begin{tabular}{cllcc}
\hline Rank & & Journal Title & $\begin{array}{c}\text { Total } \\
\text { published in } \\
\text { the sample }\end{array}$ & $\begin{array}{c}\text { \% of the } \\
\text { sample } \\
\text { (approx.) }\end{array}$ \\
\hline 7 & Organizational Dynamics & 2 & $3 \%$ \\
8 & World Development & 2 & $3 \%$ \\
9 & Organization \& Environment & 2 & $3 \%$ \\
10 & Leadership Quarterly & 2 & $3 \%$ \\
\hline
\end{tabular}

Note. Source: Data collected from ISI Web of Knowledge. (n.d.). Web of Science. Retrieved from www.isiknowledge.com

We have also classified the 64 papers in our sample as to the type of paper and the nature of the research (Table 2). The categories for the type of paper include case study, empirical, review and theoretical. The most prevalent type is theoretical (29 papers, $45.3 \%$ of the sample), followed by empirical (19 papers, or 29.7\%). To determine the nature of the research, we classified the data-driven papers (empirical and case study) according to the methodology used. We determined that 21 papers were qualitative (32.8\% of the sample) and 11 were quantitative (17.2\%).

Table 2

Types of Paper and Nature of the Research

\begin{tabular}{lcclcc}
\hline Type of paper & Total & $\begin{array}{c}\text { \% of the } \\
\text { sample }\end{array}$ & Nature of the research & Total & $\begin{array}{c}\text { \% of the } \\
\text { sample }\end{array}$ \\
\hline Case Study & 13 & $20.3 \%$ & Qualitative & 21 & $32.8 \%$ \\
Empirical & 19 & $29.7 \%$ & Quantitative & 11 & $17.2 \%$ \\
Review & 3 & $4.7 \%$ & Non-Empirical & 32 & $50.0 \%$ \\
Theoretical & 29 & $45.3 \%$ & & & \\
\hline
\end{tabular}

Note. Source: Authors' computations.

\section{Authorship analysis}

The 64 articles were authored by 103 scholars (see Table 3). Maak is the most productive author, with a total of 9 articles, followed by Pless, with 8 articles.

Table 3

The Most Productive Authors on Responsible Leadership

\begin{tabular}{ccc}
\hline Rank & Reference & \# publications \\
\hline 1 & Maak, T. & 9 \\
2 & Pless, N. M. & 8 \\
3 & Waldman, D. A. & 5 \\
4 & Voegtlin, C. & 4 \\
5 & Dugan, J.P. & 3 \\
6 & Stahl, G. K. & 3 \\
\hline
\end{tabular}

Continues 
Table 3 (continued)

\begin{tabular}{ccc}
\hline Rank & Reference & \# publications \\
\hline 7 & Stumpf, S. A. & 2 \\
8 & Doh, J. P. & 2 \\
9 & Manz, C. C. & 2 \\
10 & LaRocca, M. A. & 2 \\
11 & Groves, K. S. & 2 \\
12 & Quigley, N. R. & 2 \\
13 & Pearce, C. L. & 2 \\
14 & Wassenaar, C. L. & 2 \\
\hline
\end{tabular}

Note. Source: Data collected from ISI Web of Knowledge. (n.d.). Web of Science. Retrieved from www.isiknowledge.com

We also analyzed the authors' affiliations to ascertain the institutions and countries which drive the field (Table 4). The university with the most publications is Ramon Llull University (Spain) with 8 publications, followed by Arizona State University (USA) with 7 publications and WU-Vienna (Austria) with 6 publications. As for countries, the USA is the country with the most publications (39), followed by Canada (11) and Switzerland (10).

Table 4

Authors' Affiliations (Universities and Countries)

\begin{tabular}{clccc}
\hline Rank & \multicolumn{1}{c}{ University } & \# publications & Country & \# publications \\
\hline 1 & Ramon Llull University & 8 & USA & 39 \\
2 & Arizona State University & 7 & Canada & 11 \\
3 & WU Vienna & 6 & Switzerland & 10 \\
4 & INSEAD & 5 & Austria & 8 \\
5 & University of St. Gallen & 5 & Spain & 8 \\
6 & University of Zurich & 4 & France & 7 \\
7 & Pepperdine University & 3 & South Africa & 5 \\
8 & University of Maryland & 3 & United Kingdom & 5 \\
9 & University of Massachusetts & 3 & China & 5 \\
10 & Villanova University & 3 & Australia & 4 \\
\hline
\end{tabular}

Note. Source: Data collected from ISI Web of Knowledge. (n.d.). Web of Science. Retrieved from www.isiknowledge.com

\section{Citation analysis}

The 64 articles in the sample used a total of 4,115 references. Examining in detail all the 4,115 references would be almost impracticable. Thus, we computed the frequencies of use to assess the most used references. Table 5 shows the 25 most cited works by the 64 articles in the sample. These are arguably the most influential works related to responsible leadership. The article Responsible leadership in a stakeholder society: A relational perspective, conducted by Maak and Pless (2006b), is cited by 31 articles in the sample - about half of the sample (48\%). 
Table 5

The 25 Most-cited Works on Responsible Leadership

\begin{tabular}{|c|c|c|c|c|c|c|}
\hline Rank & Reference & $\begin{array}{l}\text { Citation } \\
\text { Frequency }\end{array}$ & $\begin{array}{c}\text { Citation } \\
\%\end{array}$ & Type & Sample & Main findings \\
\hline 1 & $\begin{array}{l}\text { Maak, T., \& Pless, N. M. (2006b). } \\
\text { Responsible leadership in a stakeholder } \\
\text { society - A relational perspective. } \\
\text { Journal of Business Ethics, 66(1), 99- } \\
\text { 115. https://doi.org/10.1007/s10551- } \\
\text { 006-9047-z }\end{array}$ & 31 & $48 \%$ & Theoretical & --- & $\begin{array}{l}\text { Under the stakeholder theory, leadership goes further that the traditional } \\
\text { leader-follower concepts; the leader becomes a coordinator and a } \\
\text { cultivator of relationships towards different stakeholder groups inside and } \\
\text { outside the corporation; } \\
\text { A (responsible) leader's roles is modeled*: The leader as steward, as } \\
\text { citizen, as visionary, as servant, as coach, as architect, as storyteller and } \\
\text { meaning enabler, as change agent. }\end{array}$ \\
\hline 2 & $\begin{array}{l}\text { Waldman, D. A., \& Galvin, B. M. } \\
\text { (2008). Alternative perspectives of } \\
\text { responsible leadership. Organizational } \\
\text { Dynamics, 37(4), 327-341. } \\
\text { https://doi.org/10.1016/j.orgdyn.2008.0 } \\
7.001\end{array}$ & 18 & $28 \%$ & Theoretical & --- & $\begin{array}{l}\text { Despite several characterizations of exemplary leadership put forward in } \\
\text { recent years (terms such as transformational, charismatic, authentic, } \\
\text { ethical, participative, servant, shared, and spiritual) authors propose that } \\
\text { the responsibility element is missing from these descriptors; } \\
\text { Authors discuss to whom and what are leaders responsible, define the } \\
\text { parameters of responsible leadership, and give suggestions for } \\
\text { implementation in an organizational setting. }\end{array}$ \\
\hline 3 & $\begin{array}{l}\text { Brown, M. E., \& Treviño, L. K. (2006). } \\
\text { Ethical leadership: A review and future } \\
\text { directions. The Leadership Quarterly, } \\
\text { 17(6), 595-616. } \\
\text { https://doi.org/10.1016/j.leaqua.2006.10 } \\
.004\end{array}$ & 18 & $28 \%$ & $\begin{array}{c}\text { Literature } \\
\text { review }\end{array}$ & --- & $\begin{array}{l}\text { Focuses on the construct of ethical leadership and spiritual, authentic, and } \\
\text { transformational leadership; } \\
\text { Intersecting the literature of the ethics and leadership, sixteen } \\
\text { propositions about the antecedents and outcomes of ethical leadership are } \\
\text { proposed; } \\
\text { Ethical leaders are honest, caring, and principled individuals who make } \\
\text { fair and balanced decisions; frequently communicate with their followers } \\
\text { about ethics, set clear ethical standards and use rewards and punishments } \\
\text { to see that those standards are followed; do not just talk a good game-- } \\
\text { they practice what they preach and are proactive role models for ethical } \\
\text { conduct. }\end{array}$ \\
\hline
\end{tabular}

Continues 


\section{Table 5 (continued)}

\begin{tabular}{|c|c|c|c|c|c|c|}
\hline Rank & Reference & $\begin{array}{l}\text { Citation } \\
\text { Frequency }\end{array}$ & $\begin{array}{c}\text { Citation } \\
\%\end{array}$ & Type & Sample & Main findings \\
\hline 4 & $\begin{array}{l}\text { Pless, N. M. (2007). Understanding } \\
\text { responsible leadership: Role identity } \\
\text { and motivational drivers. Journal of } \\
\text { Business Ethics, 74(4), 437-456. } \\
\text { https://doi.org/10.1007/s10551-007- } \\
\text { 9518-x }\end{array}$ & 16 & $25 \%$ & Case Study & $\begin{array}{l}\text { Anita Roddick, } \\
\text { Founder of The } \\
\text { Body Shop }\end{array}$ & $\begin{array}{l}\text { Biographical analysis to understand the behavior and identity script of } \\
\text { Anita Roddick as a widely recognized case of a prototype of a responsible } \\
\text { leader. }\end{array}$ \\
\hline 5 & $\begin{array}{l}\text { Waldman, D. A., \& Siegel, D. (2008). } \\
\text { Defining the socially responsible leader. } \\
\text { The Leadership Quarterly, 19(1), 117- } \\
131 \text {. } \\
\text { https://doi.org/10.1016/j.leaqua.2007.12 } \\
.008\end{array}$ & 15 & $23 \%$ & Letters & --- & $\begin{array}{l}\text { Series of letters between David Waldman and Donald Siegel debating the } \\
\text { drivers of socially responsible decisions and actions undertaken by } \\
\text { leaders. }\end{array}$ \\
\hline 6 & $\begin{array}{l}\text { Doh, J. P., \& Stumpf, S. A. (Eds.). } \\
\text { (2005). Handbook on responsible } \\
\text { leadership and governance in global } \\
\text { business. Northampton, MA: Edward } \\
\text { Elgar Publishing. }\end{array}$ & 15 & $23 \%$ & Book & --- & $\begin{array}{l}\text { Reviews the academic research on CSR, providing new perspectives on } \\
\text { CSR and the debates around it. }\end{array}$ \\
\hline 7 & $\begin{array}{l}\text { Donaldson, T., \& Preston, L. E. (1995). } \\
\text { The stakeholder theory of the } \\
\text { corporation: Concepts, evidence, and } \\
\text { implications. Academy of Management } \\
\text { Review, 20(1), 65-91. } \\
\text { https://doi.org/10.2307/258887 }\end{array}$ & 14 & $22 \%$ & Theoretical & --- & $\begin{array}{l}\text { Examine the three aspects (descriptive accuracy, instrumental power, and } \\
\text { normative validity) of the stakeholder theory and critique and integrate } \\
\text { important contributions to the literature related to each. }\end{array}$ \\
\hline 8 & $\begin{array}{l}\text { Maak, T. (2007). Responsible } \\
\text { leadership, stakeholder engagement, and } \\
\text { the emergence of social capital. Journal } \\
\text { of Business Ethics, 74(4), 329-343. } \\
\text { https://doi.org/10.1007/s10551-007- } \\
\text { 9510-5 }\end{array}$ & 14 & $22 \%$ & Theoretical & --- & $\begin{array}{l}\text { Responsible leadership contributes to building social capital and } \\
\text { ultimately to both a sustainable business and the common good, }\end{array}$ \\
\hline
\end{tabular}


Table 5 (continued)

\begin{tabular}{|c|c|c|c|c|c|c|}
\hline Rank & Reference & $\begin{array}{l}\text { Citation } \\
\text { Frequency }\end{array}$ & $\begin{array}{c}\text { Citation } \\
\%\end{array}$ & Type & Sample & Main findings \\
\hline 9 & $\begin{array}{l}\text { Maak, T., \& Pless, N. M. (Eds.). } \\
\text { (2006a). Responsible leadership. } \\
\text { London: Routledge. }\end{array}$ & 14 & $22 \%$ & Book & --- & $\begin{array}{l}\text { Several chapters on Responsible Leadership conceptualization and on } \\
\text { future leadership. In practice. }\end{array}$ \\
\hline 10 & $\begin{array}{l}\text { Freeman, R. E. (1984). Stakeholder } \\
\text { management: Framework and } \\
\text { philosophy. Mansfield, MA: Pitman. }\end{array}$ & 13 & $20 \%$ & Book & --- & $\begin{array}{l}\text { Contrary to the limited shareholder view, the stakeholder perspective } \\
\text { assumes that each organization has responsibilities to multiple groups, } \\
\text { hence management needs to develop business code of ethics, and values } \\
\text { and morals in managing their organizations, such that they respond to the } \\
\text { due interests of such groups. }\end{array}$ \\
\hline 11 & $\begin{array}{l}\text { Ghoshal, S. (2005). Bad management } \\
\text { theories are destroying good management } \\
\text { practices. Academy of Management } \\
\text { Learning \& Education, 4(1), 75-91. } \\
\text { https://doi.org/10.5465/amle.2005.161325 } \\
58\end{array}$ & 13 & $20 \%$ & Theoretical & --- & $\begin{array}{l}\text { Bad theories destroy good practices; } \\
\text { "By propagating ideologically inspired amoral theories, business schools } \\
\text { have actively freed their students from any sense of moral responsibility" } \\
\text { (p. 76). }\end{array}$ \\
\hline 12 & $\begin{array}{l}\text { Burns, J. M. (1978). Leadership. New } \\
\text { York: Harper \& Row. }\end{array}$ & 12 & $19 \%$ & Book & --- & $\begin{array}{l}\text { Classic text on the study of leadership, ranging from the transactional to } \\
\text { the transformational leadership. }\end{array}$ \\
\hline 13 & $\begin{array}{l}\text { Voegtlin, C., Patzer, M., \& Scherer, A. } \\
\text { G. (2012). Responsible leadership in } \\
\text { global business: A new approach to } \\
\text { leadership and its multi-level outcomes. } \\
\text { Journal of Business Ethics, 105(1), 1- } \\
\text { 16. https://doi.org/10.1007/s10551-011- } \\
\text { 0952-4 }\end{array}$ & 12 & $19 \%$ & Theoretical & --- & $\begin{array}{l}\text { New model of responsible leadership, drawing on deliberative practices } \\
\text { and discursive conflict resolution, combining the macro-view of the } \\
\text { business firm as a political actor with the micro-view of leadership. }\end{array}$ \\
\hline 14 & $\begin{array}{l}\text { Margolis, J. D., \& Walsh, J. P. (2003). } \\
\text { Misery loves companies: Rethinking } \\
\text { social initiatives by business. } \\
\text { Administrative Science Quarterly, 48(2), } \\
\text { 268-305. } \\
\text { https://doi.org/10.2307/3556659 }\end{array}$ & 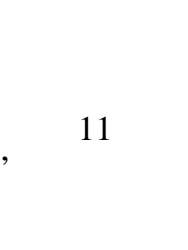 & 17 & Theoretical & & $\begin{array}{l}\text { Authors rethink social initiatives by business in order to reveal the } \\
\text { dimensions of organizational responses to misery and to assess how } \\
\text { organization theory and empirical research have thus far responded to the } \\
\text { relationship between corporate involvement in wider social life. }\end{array}$ \\
\hline
\end{tabular}

Continues 


\section{Table 5 (continued)}

\begin{tabular}{|c|c|c|c|c|c|c|}
\hline Rank & Reference & $\begin{array}{l}\text { Citation } \\
\text { Frequency }\end{array}$ & $\begin{array}{l}\text { Citation } \\
\%\end{array}$ & Type & Sample & Main findings \\
\hline 15 & $\begin{array}{l}\text { McWilliams, A., \& Siegel, D. (2001). } \\
\text { Corporate social responsibility: A } \\
\text { theory of the firm perspective. Academy } \\
\text { of Management Review, 26(1), 117-127. } \\
\text { 10.5465/AMR.2001.4011987 }\end{array}$ & 10 & $16 \%$ & Theoretical & --- & $\begin{array}{l}\text { A new model of supply and demand of CSR is proposed; } \\
\text { Authors suggest that a firm's level of CSR will depend on its size, level of } \\
\text { diversification, R\&D, advertising, government sales, consumer income, } \\
\text { labor market conditions and stage in the industry life cycle; } \\
\text { Authors conclude that there will be an ideal level of CSR; } \\
\text { They also predict that there will generally be a neutral relationship } \\
\text { between CSR activity and firm financial performance. }\end{array}$ \\
\hline 16 & $\begin{array}{l}\text { Luque, M. S. de, Washburn, N. T., } \\
\text { Waldman, D. A., \& House, R. J. (2008). } \\
\text { Unrequited profit: How stakeholder and } \\
\text { economic values relate to subordinates' } \\
\text { perceptions of leadership and firm } \\
\text { performance. Administrative Science } \\
\text { Quarterly, 53(4), 626-654. } \\
\text { https://doi.org/10.2189/asqu.53.4.626 }\end{array}$ & 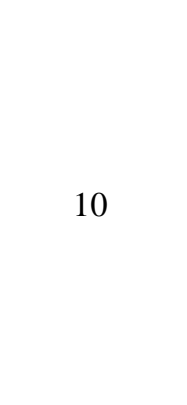 & $16 \%$ & Empirical & $\begin{array}{l}\text { surveys of } \\
\text { CEOs and two } \\
\text { subsets of } \\
\text { followers; } \\
520 \text { firms; } \\
17 \text { countries; } \\
2000-2003\end{array}$ & $\begin{array}{l}\text { Examine the indirect effects of executives' stakeholder and economic } \\
\text { values on firm performance through their followers' perceptions of } \\
\text { leadership and followers' extra effort; } \\
\text { CEOs' emphasis on economic values is associated with followers' } \\
\text { perceptions of autocratic leadership; } \\
\text { CEOs' emphasis on stakeholder values is associated with followers' } \\
\text { perceptions of visionary leadership; } \\
\text { Visionary leadership relates positively to employees' extra effort, which } \\
\text { in turn relates to firm performance. }\end{array}$ \\
\hline 17 & $\begin{array}{l}\text { Bass, B. M., \& Steidlmeier, P. (1999). } \\
\text { Ethics, character, and authentic } \\
\text { Transformational leadership behavior. } \\
\text { The Leadership Quarterly, 10(2), 181- } \\
\text { 217. https://doi.org/10.1016/s1048- } \\
\text { 9843(99)00016-8 }\end{array}$ & 9 & $14 \%$ & Theoretical & --- & $\begin{array}{l}\text { Argues that truly transformational leadership must be grounded in moral } \\
\text { foundations. }\end{array}$ \\
\hline 18 & $\begin{array}{l}\text { Pless, N. M., \& Maak, T. (2011). } \\
\text { Responsible leadership: Pathways to the } \\
\text { future. Journal of Business Ethics, } \\
98(1), 3-13 . \\
\text { https://doi.org/10.1007/978-94-007- } \\
\text { 3995-6_2 }\end{array}$ & 9 & $14 \%$ & Theoretical & --- & $\begin{array}{l}\text { Summarizes the existing relevant research on Responsible Leadership and } \\
\text { suggests future research avenues. A comparison of Responsible } \\
\text { Leadership with related leadership theories such as transformational, } \\
\text { ethical, servant, authentic leadership, is made. }\end{array}$ \\
\hline
\end{tabular}

Continues 
Table 5 (continued)

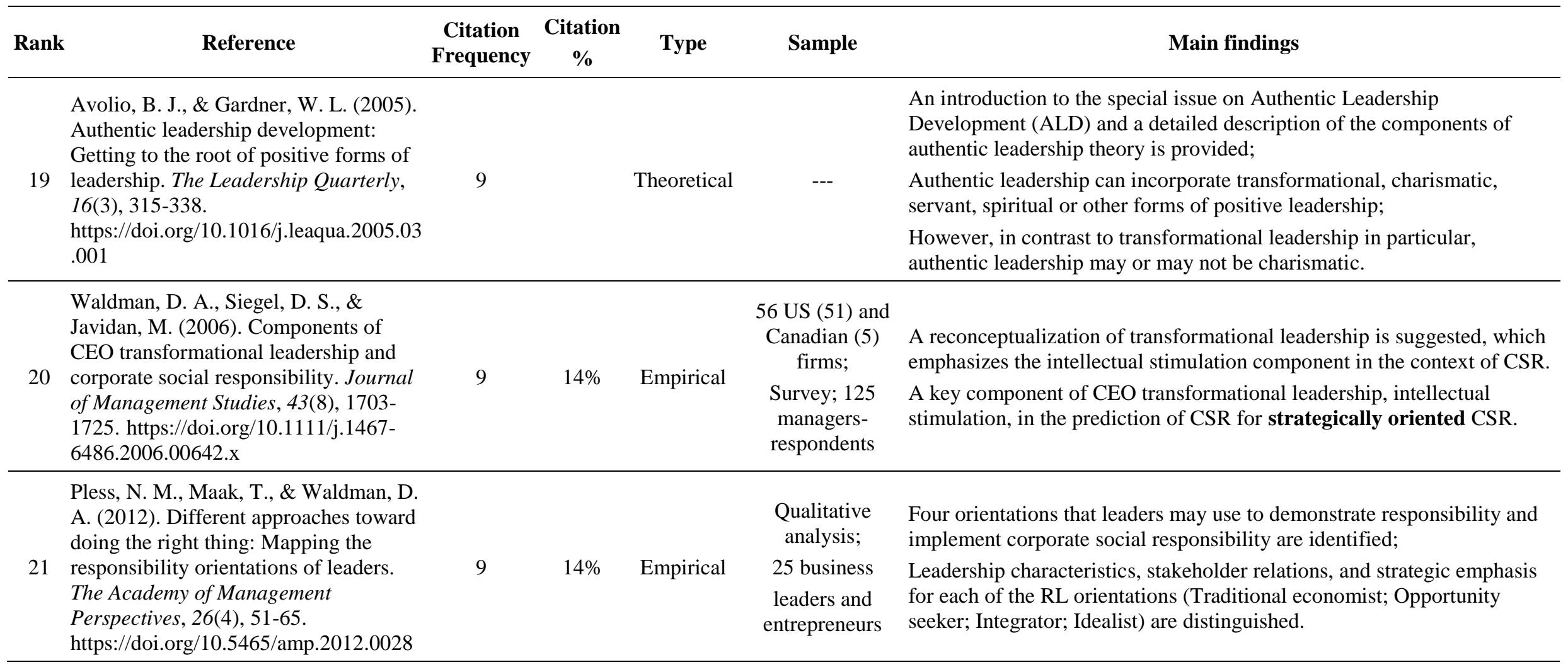

Continues 


\section{Table 5 (continued)}

\begin{tabular}{|c|c|c|c|c|c|c|}
\hline Rank & Reference & $\begin{array}{l}\text { Citation } \\
\text { Frequency }\end{array}$ & $\begin{array}{c}\text { Citation } \\
\%\end{array}$ & Type & Sample & Main findings \\
\hline 22 & $\begin{array}{l}\text { Brown, M. E., Treviño, L. K., \& } \\
\text { Harrison, D. A. (2005). Ethical } \\
\text { leadership: A social learning perspective } \\
\text { for construct development and testing. } \\
\text { Organizational Behavior and Human } \\
\text { Decision Processes, } 97(2), 117-134 . \\
\text { https://doi.org/10.1016/j.obhdp.2005.03. } \\
002\end{array}$ & 9 & $14 \%$ & Empirical & $\begin{array}{l}\text { Seven studies } \\
\text { with different } \\
\text { samples: MBAs } \\
\text { students, } \\
\text { employees from } \\
\text { financial services } \\
\quad \text { firm, etc. }\end{array}$ & $\begin{array}{l}\text { The viability and importance of ethical leadership construct is } \\
\text { investigated; } \\
\text { A new instrument to measure ethical leadership is developed and tested; } \\
\text { Ethical leadership is related to consideration behavior, honesty, trust in } \\
\text { the leader, interactional fairness, socialized charismatic leadership, and } \\
\text { abusive supervision, but is not subsumed by any of these; } \\
\text { Ethical leadership predicts outcomes such as perceived effectiveness of } \\
\text { leaders, followers' job satisfaction and dedication, and their willingness to } \\
\text { report problems to management. }\end{array}$ \\
\hline 23 & $\begin{array}{l}\text { Bass, B. M. (1985). Leadership and } \\
\text { performance beyond expectations. New } \\
\text { York: Free Press; Collier Macmillan. }\end{array}$ & 8 & $13 \%$ & Book & --- & $\begin{array}{l}\text { Presents original research that for the first time documents the traits of the } \\
\text { exceptional leader. }\end{array}$ \\
\hline 24 & $\begin{array}{l}\text { Maak, T., \& Pless, N. M. (2009). } \\
\text { Business leaders as citizens of the } \\
\text { world. Advancing humanism on a } \\
\text { global scale. Journal of Business Ethics, } \\
88(3), 537-550 . \\
\text { https://doi.org/10.1007/s10551-009- } \\
0122-0\end{array}$ & $x^{2}$ & $13 \%$ & Theoretical & --- & $\begin{array}{l}\text { Discusses the idea of business leaders acting as agents of } \\
\text { world benefit, taking an active co-responsibility in generating } \\
\text { solutions to problems; } \\
\text { Responsible global leaders - who are aware of the pressing problems in } \\
\text { the world, care for the needs of others, aspire to make this world a better } \\
\text { place, and act in word and deed as global and responsible citizens - are } \\
\text { needed; } \\
\text { Authors argue that business leaders should consider themselves as } \\
\text { cosmopolitan citizens and "agents of world benefit". }\end{array}$ \\
\hline 25 & $\begin{array}{l}\text { Rost, J. C. (1991). Leadership for the } \\
\text { twenty-first century. New York: Prager. }\end{array}$ & 7 & $11 \%$ & Book & --- & $\begin{array}{l}\text { Reviews the previous concept of leadership and suggests the use of the } \\
\text { ethical leadership construct in order to reconstruct understanding of } \\
\text { leadership in the post-industrial era. }\end{array}$ \\
\hline
\end{tabular}

Note. Source: Data collected from ISI Web of Knowledge. (n.d.). Web of Science. Retrieved from www.isiknowledge.com 


\section{Co-citation analysis}

The co-citation network displayed in Figure 2 was created using the 25 most cited references in the 64 articles included in the sample. The co-citation network allows two main analyses. On the one hand, the lines correspond to the intellectual bonds between the works, thus representing the co-citation links: thicker lines represent more connected works, i.e., more co-cited. On the other hand, the position of the works in the network give a notion of each work's centrality: works placed in a more central position are more important, influential, and impactful (Ferreira et al., 2014).

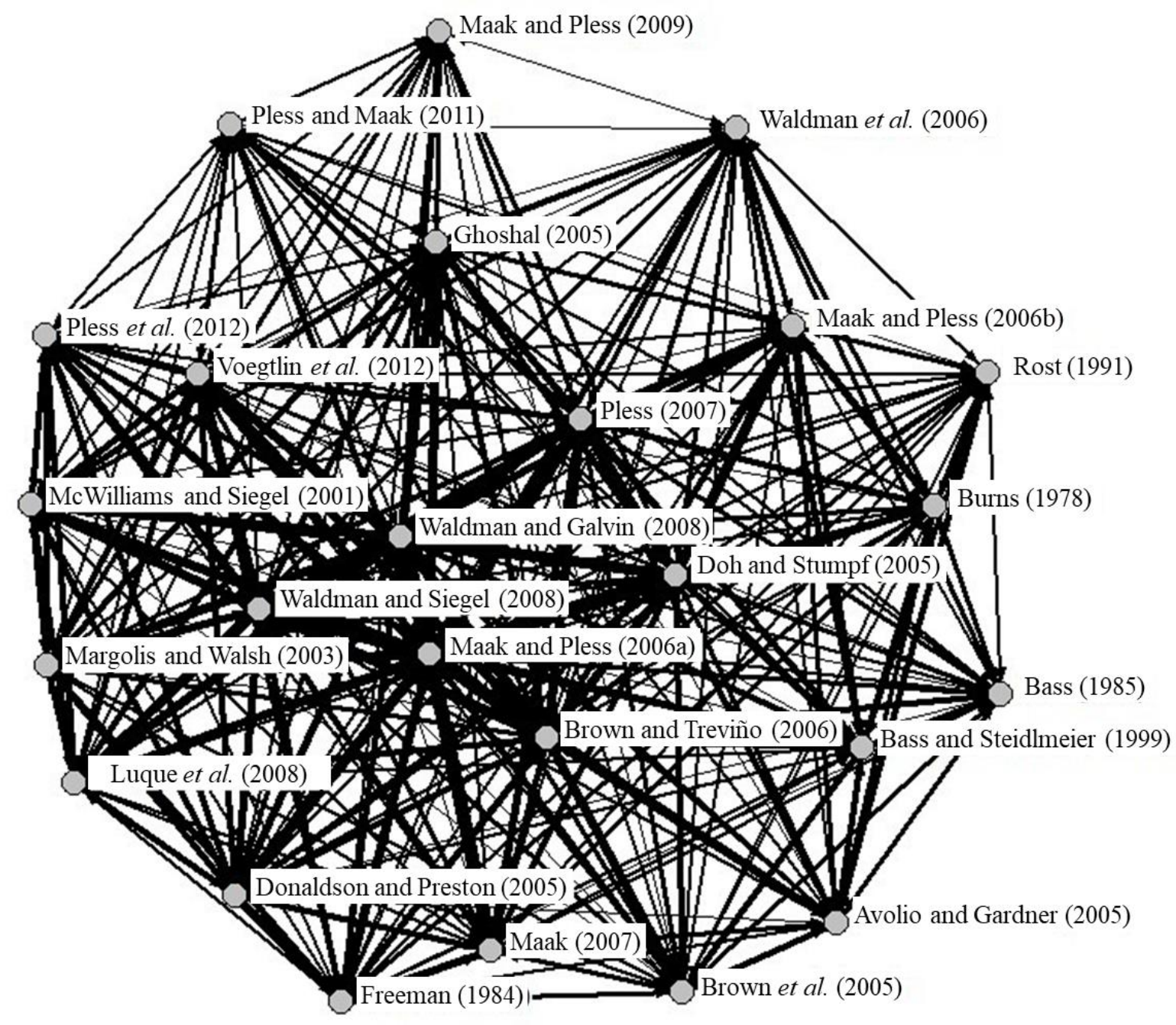

Figure 2. Co-citation Network among the Top 25 Most-cited Articles

Source: Data collected from ISI Web of Knowledge. (n.d.). Web of Science. Retrieved from www.isiknowledge.com

Based on the co-citation analysis' results, it was possible to identify a connection between the works of Maak and Pless (2006b) and Waldman and Galvin (2008). These two studies are the most cocited and, based on their central position, the most relevant in the responsible leadership research; both focus on the concept of a responsible leader and its roles and parameters. 
Table 6

Factor Analysis

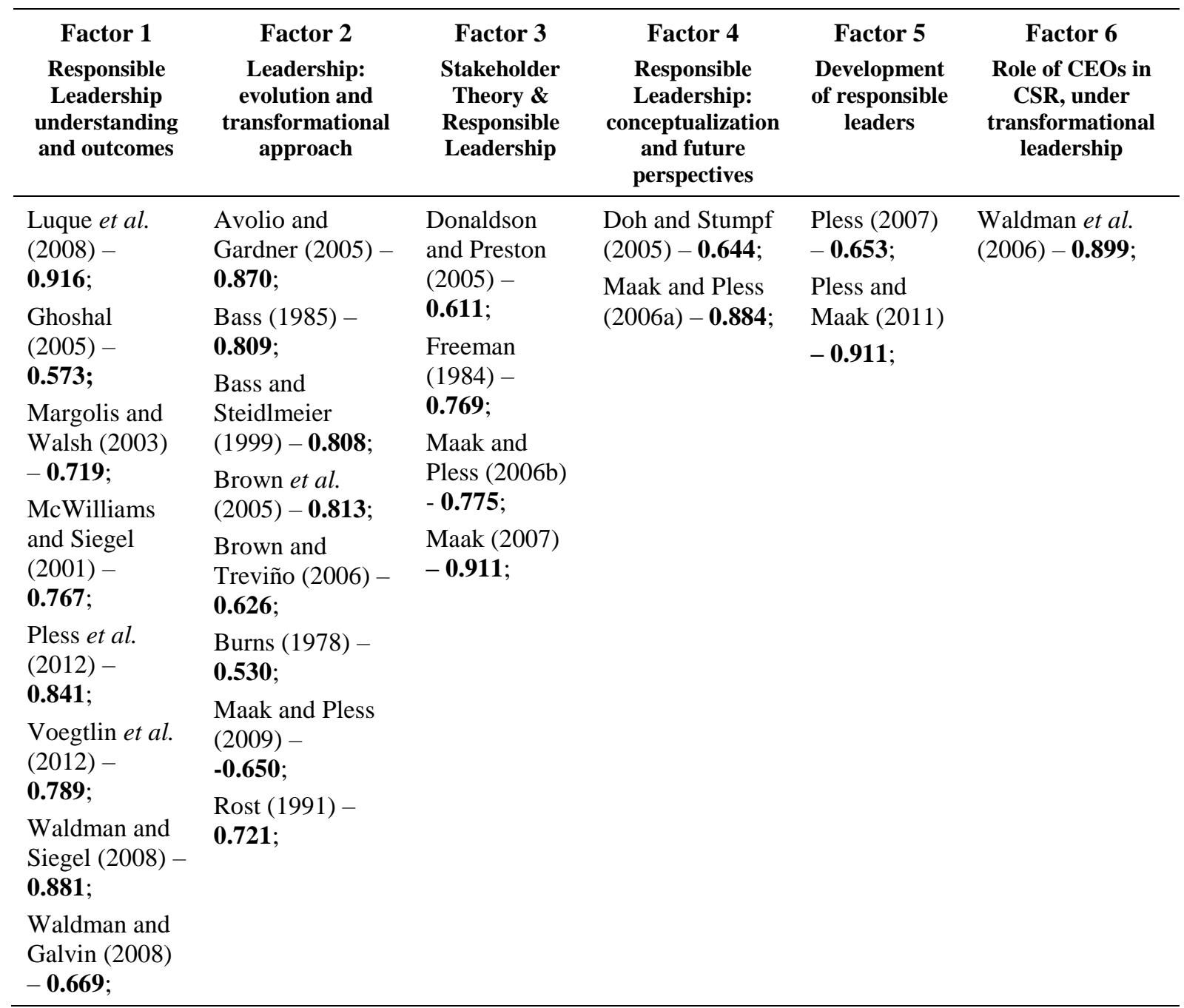

Note. Values in bold are the factor loadings.

Results of the factor analysis using the varimax rotation are shown in Table 6 . The factor analysis resulted in six factors (we retained the factors with eigenvalues greater than 1) which explain $88.9 \%$ of the variance. The first factor, explaining $35.3 \%$ of the variance was labelled Responsible Leadership understanding and outcomes, as it contains eight studies on the understanding of responsible leadership and its outcomes, across distinct levels (Voegtlin, Patzer, \& Scherer, 2012). Responsible leadership combining the macro-view of the business firm with the micro-view of leadership (Voegtlin et al., 2012), appears to be an avenue linking corporate responsibility and performance to firms' and leaders' actions (Pless, Maak, \& Waldman, 2012). When CEOs highlight stakeholder values, providing better decision-making criteria for executives, followers perceive them as visionary leaders (and less autocratic), which is positively related to employees' extra effort, which in turn relates to firm performance (Luque, Washburn, Waldman, \& House, 2008). Also other positive outcomes are proposed in this factor, such as legitimacy in decision-making, building trustful stakeholder relations based on fairness and dialogues, building social capital in formal stakeholder relations along the network, and also the ability to influence the ethical culture of an organization, that responsible leadership practices will thereby encourage a culture of discursive conflict resolution and deliberative practices (Voegtlin $e t$ al., 2012).

The second factor, which explains $26.1 \%$ of the variance - Leadership: evolution and transformational approach - includes eight studies on leadership, from the transactional to the 
transformational approach (Burns, 1978) of the late $20^{\text {th }}$ century and $21^{\text {st }}$ century (Rost, 1991). These studies demand business leaders act as agents of world benefit (Maak \& Pless, 2009), and the identified factor highlights positive forms of leadership (Avolio \& Gardner, 2005), ethical leadership (Brown \& Treviño, 2006) and its measurement (Brown, Treviño, \& Harrison, 2005), which is founded on a moral basis (Bass \& Steidlmeier, 1999), and which assumes a high level of importance in the transformational paradigm. This factor shows the leadership evolution to the transformational approach, where a more inspirational and positive form of leadership is needed when leading employees in organizations of the late $20^{\text {th }}$ century.

The third factor, accounting for $9.4 \%$ of the variance - Stakeholder Theory \& Responsible Leadership - includes four theoretical studies on the framework and concepts of the Stakeholder Theory (Donaldson \& Preston, 2005; Freeman, 1984) and also the link to the relational society of the $21^{\text {st }}$ century focused on the stakeholder engagement and demanding responsible leadership (Maak \& Pless, 2006b; Maak, 2007). This factor is composed of studies looking at a global stakeholder society, and demanding a relational and intrinsically moral leadership phenomenon (Maak, 2007). The traditional and usual relationships between parties, leaders-followers, are insufficient for today's network of relationships, thus a more relational leadership is demanded.

The fourth factor representing $8.5 \%$ of the variance - Responsible Leadership: conceptualization and future perspectives - comprehends two books on responsible leadership, its conceptualization and perspectives for future global leaders.

The fifth factor, which explains 5.4\% of the variance - Development of responsible leaders contains two studies on leadership theories and future research perspectives for responsible leadership (Pless \& Maak, 2011) and a set of behaviors of a responsible leader's perspective based on a narrative approach for analyzing the biography of Anita Roddick (Pless, 2007).

Finally, the sixth factor, which explains $4.2 \%$ of the variance - Role of CEOs in CSR, under transformational leadership theory - includes a single study which looks into the role of CEOs in determining the extent to which their firms engage in corporate social responsibility, using transformational leadership theory. Based on an empirical analysis, the study found that intellectual stimulation of CEOs is associated with propensity of firms to engage in strategic CSR (Waldman, Siegel, \& Javidan, 2006).

\section{Summary of the results}

The current investigation indicates that the responsible leadership research has started mainly in 2006 and in 2010 the researchers' interest on the topic has increased, with a correspondent number of publications. The leading journal in terms of numbers is the Journal of Business Ethics. The most prolific author is Thomas Maak, followed by Nicola Pless. The most cited study is Maak and Pless's (2006b): Responsible leadership in a stakeholder society: A relational perspective, published in 2006 . The works Maak and Pless (2006b) and Waldman and Galvin (2008) are the most co-cited and the most relevant in the responsible leadership research, focused on the concept of responsible leadership and its roles and parameters. Six factors emerged, showing six different research fields on the topic of Responsible Leadership, ranging from the evolution of leadership, to the transformational approach, from the stakeholder theory and its relationship to the responsible leadership, to the conceptualization, understanding and outcomes of responsible leadership, and also covering future perspectives and roles of responsible leaders.

\section{Discussion and Concluding Remarks}

To perform the bibliometric review of the existing research on responsible leadership, we used bibliometric techniques on 64 works on the topic published from 2006 to 2016 in journals indexed in 
SSCI database. We carried out authorship, citation, co-citation and factor analyses, aiming to explore the state-of-the-art on the topic and to suggest key features of the current investigation. This study improves the understanding of the literature and the theoretical structure that supports the field. Specifically, it points to dominant researchers and approaches in the leadership literature, such as studies, periodicals and scholars' influence, as well as works that have had the greatest impact on the field.

Despite the field of responsible leadership still being in its infancy (Shi \& Ye, 2016), a decade of research has resulted in at least 64 publications that depict several alternative emerging theories, as well as concepts and research methods and techniques (Shi \& Ye, 2016). Based on the frequency distribution of publications on the topic, which started in 2006, the number of publications grew from 2009 on, denoting the increasing research interest in responsible leadership. Critical texts include those by Maak and Pless (2006b), Waldman and Galvin (2008), Maak (2007), and Voegtlin et al. (2012), all emphasizing the need for responsibility when leading, much in the same way as the stakeholder theory (Freeman, 1984). These results also show that responsible leadership is linked with the stakeholder theory, which means that future developments in the responsible leadership theory need to take into account - or even depend on or influence - developments in stakeholder theory. For example, most of the previous authors have based their ideas on Freeman's seminal 1984 work, but further progress can result from other approaches, such as Friedman and Miles' (2002) notion of compatible versus noncompatible stakeholders' interests, or Duckworth and Moore's (2010) extension of the stakeholder theory to corporate social responsibility.

Probably due to its scope and concern on ethical issues in business, the periodical that has been leading publication is the Journal of Business Ethics. Almost half of our sample (30) of publications on responsible leadership can be found in the Journal of Business Ethics and this can assume great importance mainly because future research may focus and concentrate its effort on the Journal of Business Ethics, although other periodicals have been publishing papers on the topic. Several authors have been publishing on responsible leadership. Thomas Maak has the richest portfolio of publications, followed by Nicola Pless.

Concerning the most influential works on responsible leadership, the article Responsible leadership in a stakeholder society - a relational perspective (Maak \& Pless, 2006b), has been cited by almost half of the sample, therefore showing its centrality in the field. Maak and Pless's (2006b) text is theoretical, and it explores the concept and the different roles for a responsible leader in the $21^{\text {st }}$ century. The usual understanding of the dual relationship between leader-subordinates in the organization is considered insufficient for the multitude of relationships between all the agents, leader and followers/stakeholders; hence responsible leadership is understood as a "social-relational and ethical phenomenon, which occurs in social processes of interaction" (Maak \& Pless, 2006b, p. 99). The global and interconnected world of the $21^{\text {st }}$ century, where complexity and uncertainty emerge in businesses across the world, embedded in a general crisis of legitimacy and trust, demands a responsible leader that: (a) mobilizes employees; (b) guarantees the best product/service for the clients and customers, according to their needs; (c) ensures that ethical, labor and environmental issues are being respected by their business partners; (d) is sensitive to the impact of business decisions on the social and natural environment; and also (e) protects their shareholders' investment capital and ensures return (Maak \& Pless, 2006b). Stakeholders in this vision are various: employees, clients/customers, business partners, social/environmental institutions, and shareholders.

Based on the 25 most cited articles in the existent literature on responsible leadership, we conclude they have been conducted mainly in Western countries, and that $52 \%$ of them have a theoretical essence (theoretical/literature or reviews/letters), clearly showing the first attempts to explore the concept of responsible leadership, thus revealing a research gap. Despite having identified four empirical studies, one case study and six books on the topic, the field is still struggling to define its essence and boundaries. Thus, to fill this gap, further empirical research in this field is needed in order to clarify the concept, to reach a more mature definition, and to understand the role played by any situational factors such as culture. There is also a need to further examine the antecedents and consequences of responsible leadership, as well as the role of interactional, moderation, and mediation variables. 
Regarding the co-citation analysis performed, two main conclusions can be advanced: firstly, the connection between the works of Maak and Pless (2006b) and of Waldman and Galvin (2008). Based on their central position one may arguably assume that these works reach the most relevant status regarding the co-cited role on the topic of responsible leadership. These two works are of a theoretical nature, as both focus on the concept of responsible leadership, and its roles and parameters. Maak and Pless (2006b) based their analysis on the stakeholder theory to develop their ideas and thoughts. Thus, the popular leader-follower relationship assumes a new range of relationships since, under the stakeholder theory, the responsible leader becomes "a coordinator and a cultivator of relationships towards different stakeholder groups" (Maak \& Pless, 2006b, p. 100). The concept of follower is extended to all the numerous stakeholders from inside and outside the organization, suggesting a new view of leadership and of the leader's roles: the leader as steward, as citizen, as visionary, as servant, as coach, as architect, as storyteller, and as change agent. Waldman and Galvin (2008) point out that despite the existence of various similar constructs - transformational, charismatic, authentic, ethical, participative, servant, shared, and spiritual - the responsibility element is not completely captured in these descriptors. Therefore, Waldman and Galvin (2008) discuss to whom and what are leaders responsible for, question the parameters of responsible leadership, and suggest ways to develop responsible leadership in organizational settings. Responsibility is "the heart of what effective leadership is all about" (Waldman \& Galvin, 2008, p. 327).

Another linkage was identified between Pless's work (2007), and Doh and Stumpf's book (2005). The latter was one of the first attempts to integrate the knowledge on responsible leadership; Pless's research (2007) is the first case study on responsible leadership based on a biographical analysis to understand the behavior and identity script of Anita Roddick, the founder of Body Shop, as a prototype of a responsible leader. According to Pless (2007), ten main roles are assumed by the responsible leaders: 1 - a responsible leader is driven by a values-based vision of the future that goes beyond business considerations; 2 - responsible leadership manifests itself in defining moments, in which leaders have to make fundamental decisions with a long-term effect on people, environment and/or the future of the organization; such moments reveal the character and integrity of a leader; 3 - a responsible leader reconciles the idea of effectiveness with the idea of corporate responsibility by being an active citizen and promoting active citizenship inside and outside the organization; 4 - responsible leadership is rooted in an ethics of care driven by a desire to serve others; 5 - it requires a leader to be connected and close to stakeholders; 6 - using storytelling as a leadership method to connect to different stakeholders; 7 responsible leadership can be understood as the art of building and sustaining social and moral relationships between business leaders and different stakeholders (followers), based on a sense of justice, a sense of recognition, a sense of care and a sense of accountability for a wide range of economic, ecological, social, political and human responsibilities; 8 - a sense of responsibility is developed over time; 9 - strong moral values coupled with self-assertion, curiosity and the ability and willingness to learn are an important prerequisite to become a leader; 10 - make ethics and responsibility part of the curriculum at all levels of the educational channel.

Based on the factor analysis, six different factors emerged, thus indicating six main research fields on Responsible Leadership and its relationship with Stakeholder Theory (factor 3), and with the transformational leadership approach (factor 2), and also its connection to CSR (factor 6). Theoretical studies focused on the understanding and outcomes of Responsible Leadership (factor 1), or on its conceptualization (factor 4) are also clearly identified. Based on an overview of existing research and suggestions for future research (Pless \& Maak, 2011), only one case study is shown (factor 5), which suggests a gap: a lack of empirical studies on Responsible Leadership and scales to measure and identify a responsible leader in organizations. Furthermore, no studies on public administration appeared, thus suggesting the need for studying Responsible Leadership in a public context. Moreover, no crosscultural studies emerged, which recommends more investigation in this area.

Analyzing the most influential articles and the literature review, a more integrative definition is proposed in the present study, as it includes not only the relational component, but also the micro-level (firm), the macro-level (society), and the new focus on the problem-solving role. Responsible leaders become managers of relationships of different stakeholder groups inside and outside the firm, as well as 
managers in charge of developing sustainable businesses, via integrating micro and macro concerns. This somehow romantic view of leadership is closely following the global plea for developing more ethical and moral practices and philosophies in the business world. As Bob Dylan (1964) once wrote, "Times they are A'changin", and so too leadership times are calling for a paradigmatic change.

\section{Limitations and future research}

The first limitation of the current study is concerned with the sample. Notwithstanding that this research includes journals indexed in ISI Web of Knowledge - SSCI, other indexes and databases could have and should be included in future investigation. A wider use of databases will help clarify and expand the conclusions and streams identified in this text.

Studies published in languages different than English were not included. It is also important to explore the meaning of responsible leadership in other cultures and religions, as it is reasonable to think that Asian, Latin, and African cultures, for example, may have been dealing with similar concerns for a longer period of time than Anglo-Saxon ones.

Another limitation concerns the source of metadata for the bibliometric analyses. We have relied on Web of Science data, a database that does not include all journals. Despite being confident that our sample makes an accurate representation of the field, future research may use other databases (e.g. Science Direct) to retrieve the bibliometric data. Furthermore, additional analyses of the field may include a comprehensive search in non-indexed journals, proceedings, theses and books, so that a broader perspective of the field can be erected. Often, ground-breaking ideas come from unusual sources, such as master or doctoral dissertations, which also often never leave the desks of their authors.

The future of responsible leadership research is munificent. Based on the gaps identified in the present study, there is room for theoretical refinement of the field, namely concerning the clarification of the concept of responsible leadership, as well as the antecedents and the consequences of responsible leadership. Also, empirical analyses of the existing models and of the conceptual advancements are necessary, especially quantitative studies as the field still relies mostly on conceptual and qualitative studies. Specifically, the study of the effects of a responsible leadership style on dimensions such as organizational commitment, engagement, citizenship behaviors and performance are welcome. Furthermore, understanding the role of responsible leaders in the public sector may prove interesting, as public administrations are often viewed as lacking adequate leadership. Finally, the responsible leadership in a cross-cultural setting and in expatriate context have yet to be analyzed, thus offering an interesting avenue for future research.

\section{References}

Acedo, F. J., Barroso, C., \& Galan, J. L. (2006). The resource-based theory: Dissemination and main trends. Strategic Management Journal, 27(7), 621-636. https://doi.org/10.1002/smj.532

Avolio, B. J., \& Gardner, W. L. (2005). Authentic leadership development: Getting to the root of positive forms of leadership. The Leadership Quarterly, 16(3), 315-338. https://doi.org/10.1016/j.leaqua.2005.03.001

Bass, B. M. (1985). Leadership and performance beyond expectations. New York: Free Press; Collier Macmillan.

Bass, B. M., \& Steidlmeier, P. (1999). Ethics, character, and authentic transformational leadership behavior. The Leadership Quarterly, 10(2), 181-217. https://doi.org/10.1016/s10489843(99)00016-8 
Batistič, S., Černe, M., \& Vogel, B. (2017). Just how multi-level is leadership research? A document co-citation analysis 1980-2013 on leadership constructs and outcomes. The Leadership Quarterly, 28(1), 86-103. https://doi.org/10.1016/j.leaqua.2016.10.007

Beinhocker, E., \& Hanauer, N. (2014, September). Redefining capitalism. McKinsey Quarterly, 3(3rd quarter), 160-169. Retrieved from https://www.mckinsey.com/global-themes/long-termcapitalism/redefining-capitalism

Bjork, S., Offer, A., \& Soderberg, G. (2014). Time series citation data: The Nobel Prize in economics. Scientometrics, 98(1), 185-196. https://doi.org/10.1007/s11192-013-0989-5

Broadus, R. (1987). Toward a definition of "bibliometrics". Scientometrics, 12(5/6), 373-379. https://doi.org/10.1007/bf02016680

Brown, M. E., \& Treviño, L. K. (2006). Ethical leadership: A review and future directions. The Leadership Quarterly, 17(6), 595-616. https://doi.org/10.1016/j.leaqua.2006.10.004

Brown, M. E., Treviño, L. K., \& Harrison, D. A. (2005). Ethical leadership: A social learning perspective for construct development and testing. Organizational Behavior and Human Decision Processes, 97(2), 117-134. https://doi.org/10.1016/j.obhdp.2005.03.002

Burns, J. M. (1978). Leadership. New York: Harper \& Row.

Charvet, F. F., Cooper, M. C., \& Gardner, J. T. (2008). The intellectual structure of supply chain management: A bibliometric approach. Journal of Business Logistics, 29(1), 47-73. https://doi.org/10.1002/j.2158-1592.2008.tb00068.x

Cullen, J. G. (2015). Educating business students about sustainability: A bibliometric review of current trends and research needs. Journal of Business Ethics, 145(2), 429-439. https://doi.org/10.1007/s10551-015-2838-3

Diodato, V. (1994). Dictionary of bibliometrics. Binghamton, NY: Haworth Press.

Doh, J. P., \& Stumpf, S. A. (Eds.). (2005). Handbook on responsible leadership and governance in global business. Edward Elgar Publishing.

Donaldson, T., \& Preston, L. E. (1995). The stakeholder theory of the corporation: Concepts, evidence, and implications. Academy of Management Review, 20(1), 65-91. https://doi.org/10.2307/258887

Duckworth, H. A., \& Moore, R. A. (2010). Social responsibility: Failure mode effects and analysis. Boca Raton, FL: CRC Press.

Dylan, B. (1964). The times they are a-changin'. The times they are a-changin' [Vinyl record]. New York: Columbia Records.

Ferreira, M. P. (2011). A bibliometric study on Ghoshal's managing across borders. Multinational Business Review, 19(4), 357-375. https://doi.org/10.1108/15253831111190180

Ferreira, M. P., Li, D., Reis, N. R., \& Serra, F. R. (2014). Culture in international business research: A bibliometric study in four top IB journals. Management Research, 12(1), 68-91. https://doi.org/10.1108/mrjiam-04-2012-0482

Freeman, R. E. (1984). Stakeholder management: Framework and philosophy. Mansfield, MA: Pitman.

Friedman, A. L., \& Miles, S. (2002). Developing stakeholder theory. Journal of Management Studies, 39(1), 1-21. http://dx.doi.org/10.1111/1467-6486.00280 
Furrer, O., Thomas, H., \& Goussevskaia, A. (2008). The structure and evolution of the strategic management field: A content analysis of 26 years of strategic management research. International Journal of Management Reviews, 10(1), 1-23. https://doi.org/10.1111/j.1468-2370.2007.00217.x

Ghoshal, S. (2005). Bad management theories are destroying good management practices. Academy of Management Learning \& Education, 4(1), 75-91. https://doi.org/10.5465/amle.2005.16132558

Gurzki, H., \& Woisetschläger, D. M. (2017). Mapping the luxury research landscape: A bibliometric citation analysis. Journal of Business Research, 77, 147-166. https://doi.org/10.1016/j.jbusres.2016.11.009

Hood, W., \& Wilson, C. (2001). The literature of bibliometrics, scientometrics, and informetrics. Scientometrics, 52(2), 291-314. https://doi.org/10.1023/A:1017919924342

Howell, J. M., \& Avolio, B. J. (1993). Transformational leadership, transactional leadership, locus of control, and support for innovation: Key predictors of consolidated-business-unit performance. Journal of Applied Psychology, 78(6), 891. https://doi.org/10.1037//0021-9010.78.6.891

ISI Web of Knowledge. (n.d.). Web of Science. Retrieved from www.isiknowledge.com

Lindahl, J., Stenling, A., Lindwall, M., \& Colliander, C. (2015). Trends and knowledge base in sport and exercise psychology research: A bibliometric review study. International Review of Sport and Exercise Psychology, 8(1), 71-94. https://doi.org/10.1080/1750984x.2015.1019540

López-Duarte, C., Vidal-Suárez, M. M., González-Díaz, B., \& Reis, N. R. (2016). Understanding the relevance of national culture in international business research: A quantitative analysis. Scientometrics, 108(3), 1553-1590. https://doi.org/10.1007/s11192-016-2044-9

Luque, M. S. de, Washburn, N. T., Waldman, D. A., \& House, R. J. (2008). Unrequited profit: How stakeholder and economic values relate to subordinates' perceptions of leadership and firm performance. Administrative Science Quarterly, 53(4), 626-654. https://doi.org/10.2189/asqu.53.4.626

Maak, T. (2007). Responsible leadership, stakeholder engagement, and the emergence of social capital. Journal of Business Ethics, 74(4), 329-343. https://doi.org/10.1007/s10551-007-9510-5

Maak, T., \& Pless, N. M. (2006a). Responsible leadership. London: Routledge.

Maak, T., \& Pless, N. M. (2006b). Responsible leadership in a stakeholder society - A relational perspective. Journal of Business Ethics, 66(1), 99-115. https://doi.org/10.1007/s10551-006-9047-z

Maak, T., \& Pless, N. M. (2009). Business leaders as citizens of the world: Advancing humanism on a global scale. Journal of Business Ethics, 88(3), 537-550. https://doi.org/10.1007/s10551-0090122-0

Ma, Z. (2009). The status of contemporary business ethics research: Present and future. Journal of Business Ethics, 90(S3), 255-265. https://doi.org/10.1007/s10551-010-0420-6

Margolis, J. D., \& Walsh, J. P. (2003). Misery loves companies: Rethinking social initiatives by business. Administrative Science Quarterly, 48(2), 268-305. https://doi.org/10.2307/3556659

McWilliams, A., \& Siegel, D. (2001). Corporate social responsibility: A theory of the firm perspective. Academy of Management Review, 26(1), 117-127. http://dx.doi.org/10.5465/AMR.2001.4011987

Persson, O., Danell, R., \& Wiborg, S. J. (2009). How to use Bibexcel for various types of bibliometric analysis. In F. Åström, R. Danell, B. Larsen, \& J. Schneider (Eds.), Celebrating scholarly communication studies: A Festschrift for Olle Persson at his 60th Birthday (pp. 9-24). Leuven, Belgium: International Society for Scientometrics and Informetrics. 
Pfeffer, J. (2015). Leadership BS. Fixing workplaces and careers one truth at a time. New York: Harper Collins.

Pinto, C. F., Serra, F. R., \& Ferreira, M. P. (2014). A bibliometric study on culture research in International Business. BAR - Brazilian Administration Review, 11(3), 340-363. Retrieved from http://www.scielo.br/pdf/bar/v11n3/1807-7692-bar-11-3-0340.pdf.

https://dx.doi.org/10.1590/1807-7692bar2014309

Pless, N. M. (2007). Understanding responsible leadership: Role identity and motivational drivers. Journal of Business Ethics, 74(4), 437-456. https://doi.org/10.1007/s10551-007-9518-x

Pless, N. M., \& Maak, T. (2011). Responsible leadership: Pathways to the future. Journal of Business Ethics, 98(1), 3-13. https://doi.org/10.1007/978-94-007-3995-6_2

Pless, N. M., Maak, T., \& Waldman, D. A. (2012). Different approaches toward doing the right thing: Mapping the responsibility orientations of leaders. The Academy of Management Perspectives, 26(4), 51-65. https://doi.org/10.5465/amp.2012.0028

Pritchard, A. (1969). Statistical bibliography or bibliometrics?. Journal of Documentation, 25(4), 348349.

Ramos-Rodríguez, A. R., \& Ruíz-Navarro, J. (2004). Changes in the intellectual structure of strategic management research: A bibliometric study of the Strategic Management Journal, 1980-2000. Strategic Management Journal, 25(10), 981-1004. https://doi.org/10.1002/smj.397

Rost, J. C. (1991). Leadership for the twenty-first century. New York: Prager.

Shi, Y., \& Ye, M. (2016). Responsible leadership: review and prospects. American Journal of Industrial and Business Management, 6(8), 877-884. https://doi.org/10.4236/ajibm.2016.68083

Sriwannawit, P., \& Sandström, U. (2015). Large-scale bibliometric review of diffusion research. Scientometrics, 102(2), 1615-1645. https://doi.org/10.1007/s11192-014-1448-7

Stogdill, R. M. (1950). Leadership, membership and organization. Psychological Bulletin, 47(1), 1-14. https://doi.org/10.1037/h0053857

Tal, D., \& Gordon, A. (2016). Leadership of the present, current theories of multiple involvements: A bibliometric analysis. Scientometrics, 107(1), 259-269. https://doi.org/10.1007/s11192-016$1880-\mathrm{y}$

Teixeira, M. L. M., Iwamoto, H. M., \& Medeiros, A. L. (2013). Bibliometric studies (?) In Administration: discussing the transposition of purpose. Administração: Ensino e Pesquisa, 14(3), 423-452. https://doi.org/10.13058/raep.2013.v14n3.57

Oorschot, J. van, Hofman, E., \& Halman, J. (2015). A bibliometric review of the innovation adoption $\begin{array}{lllll}\text { literature. Academy of Management Proceedings, } & 2015(1), & 16847 .\end{array}$ https://doi.org/10.5465/ambpp.2015.16847abstract

Voegtlin, C., Patzer, M., \& Scherer, A. G. (2012). Responsible leadership in global business: A new approach to leadership and its multi-level outcomes. Journal of Business Ethics, 105(1), 1-16. https://doi.org/10.1007/s10551-011-0952-4

Vogel, R., \& Masal, D. (2015). Public leadership: A review of the literature and framework for future research. Public Management Review, 17(8), 1165-1189. https://doi.org/10.1080/14719037.2014.895031

Waldman, D. A., \& Galvin, B. M. (2008). Alternative perspectives of responsible leadership. Organizational Dynamics, 37(4), 327-341. https://doi.org/10.1016/j.orgdyn.2008.07.001 
Waldman, D. A., \& Siegel, D. (2008). Defining the socially responsible leader. The Leadership Quarterly, 19(1), 117-131. https://doi.org/10.1016/j.leaqua.2007.12.008

Waldman, D. A., Siegel, D. S., \& Javidan, M. (2006). Components of CEO transformational leadership and corporate social responsibility. Journal of Management Studies, 43(8), 1703-1725. https://doi.org/10.1111/j.1467-6486.2006.00642.x

Wang, G. G., Gilley, J. W., \& Sun, J. Y. (2012). The "science of HRD research:” Reshaping HRD research through scientometrics. Human Resource Development Review, 11(4), 500-520. https://doi.org/10.1177/1534484312452265

Wang, G., Oh, I. S., Courtright, S. H., \& Colbert, A. E. (2011). Transformational leadership and performance across criteria and levels: A meta-analytic review of 25 years of research. Group \& Organization Management, 36(2), 223-270. https://doi.org/10.1177/1059601111401017

White, H. D., \& McCain, K. W. (1998). Visualizing a discipline: An author co-citation analysis of information science. Journal of the American Society for Information Science, 49(4), 327-355. https://doi.org/10.1002/(sici)1097-4571(19980401)49:4\%3C327::aid-asi4\%3E3.0.co;2-w

Williams, J. K., Tripp-Reimer, T., Daack-Hirsch, S., \& DeBerg, J. (2016). Five-year bibliometric review of genomic nursing science research. Journal of Nursing Scholarship, 48(2), 179-186. https://doi.org/10.1111/jnu.

Yukl, G. (2006). Leadership in organizations (6th ed.). Upper Saddle River, NJ: Pearson-Prentice Hall.

\section{Authors' Profiles}

Tânia Marques

School of Technology and Management, CARME - Centre of Applied Research in Management and Economics, Polytechnic Institute of Leiria, Morro do Lena - Alto Vieiro, 2411-901, Leiria, Portugal. E-mail address: taniamarques@ipleiria.pt. https://orcid.org/0000-0003-0492-6233

Nuno Reis

School of Technology and Management, CARME - Centre of Applied Research in Management and Economics, Polytechnic Institute of Leiria, Morro do Lena - Alto Vieiro, 2411-901, Leiria, Portugal. E-mail address: nuno.m.reis@ipleiria.pt. https://orcid.org/0000-0002-4544-0312

Jorge F. S. Gomes

Advance/CSG, ISEG, Universidade de Lisboa, Rua do Quelhas, 6, 1249-078, Lisbon, Portugal. E-mail address: jorgegomes@iseg.ulisboa.pt. https://orcid.org/0000-0003-0694-2229 